\title{
Segregação socioespacial e luta por moradia na Grande Florianópolis: raízes e características da Ocupação Contestado
}

\author{
Socio-spatial segregation and struggle for housing in Florianópolis: \\ Roots and characteristics of the Contestado Occupation
}

http://dx.doi.org/10.5007/2178-4582.2015v49n2p224

\author{
Luís Felipe Aires Magalhães e Vitor Hugo Tonin \\ Universidade Estadual de Campinas, Campinas/SP, Brasil
}

\begin{abstract}
Este artigo tem como objetivo narrar a experiência de criação e desenvolvimento da Ocupação Contestado a partir de um contexto mais geral de acúmulo de contradições urbanas na região da Grande Florianópolis. Pretende-se, com isto, refletir teoricamente sobre estas contradições, reveladas sobretudo por um processo de segregação sócio-espacial na região, avaliando a sua relação com os processos migratórios recentes, o crescimento demográfico nas principais cidades (Florianópolis, São José, Biguaçú e Palhoça) e o ressurgimento do movimento de luta por moradia, particularmente a partir da Ocupação Contestado. Com base em trabalho de campo, apresentamos as principais características de sua demografia social, buscando avaliar em que medida a experiência dos moradores da ocupação expressam tendências vigentes na mobilidade espacial e na dinâmica intraurbana da região.
\end{abstract}

Palavras-chave: Segregação sócio-espacial, Luta por moradia, Ocupação Contestado, Florianópolis.
This article aims to narrate the experience of creation and development of the Contestado Occupation from a more general context of urban accumulation of contradictions in the Greater Florianópolis region. Thus, it is intended to reflect theoretically on these contradictions, especially revealed by a socio-spatial segregation process in the region, evaluating its relationship with the recent migration processes, population growth in major cities (Florianópolis, São José, Biguaçú and hut) and the resurgence of the struggle movement for housing, particularly the Contestado Occupation. Based on fieldwork research, we present the main features of their social demographics, seeking to assess to what extent the experience of occupation of residents express current trends in spatial mobility and intra-urban dynamics in the region.

Keywords: Socio-spatial segregation; Struggle for housing, Contestado Occupation; Florianópolis.

\section{Introdução}

A Região da Grande Florianópolis passou por um intenso crescimento urbano nas últimas décadas, impulsionado por processos de expulsão populacional de pequenos agricultores provenientes de outras regiões catarinenses e outros Estados (MIOTO, 2008). Internamente, desde o início do século XX a expansão da ocupação urbana promoveu as primeiras pressões econômicas e sociais que removeram a população pobre e negra que habitava o centro da cidade e que passou a fixar-se em áreas de encostas do Maciço Central do 
Morro da Cruz. "Os morros da Mariquinha e do Mocotó foram ocupados por homens e mulheres de baixa renda, sendo que muitos eram ex-escravos que trabalhavam em casas de família na área central de Florianópolis ou no mercado público da cidade" (DANTAS; VENDRAMINI, 2011, p. 159).

Nas décadas seguintes, as ideologias de higienismo urbano (já presentes em outros centros urbanos do país), promoveram a identificação e posterior segregação das classes subalternas. Escravos libertos e descendentes deles, além de imigrantes pobres, passam a sofrer pressões para sua concentração nas áreas de encostas, liberando o espaço do centro urbano para um projeto elitista de ocupação econômica e social. O poder público sempre esteve envolvido neste processo de segregação urbana1, seja através do crime eleitoral que, como veremos, condicionará a criação da Ocupação Contestado, seja através da orientação dos projetos habitacionais populares para regiões afastadas do centro urbano, e, ainda, por meio da viabilização da ocupação de áreas precárias, também afastadas do centro da cidade.

A ocupação dos morros foi facilitada pelas medidas sanitárias do governo catarinense que desmatou grande parte destas áreas, justificando que a densidade das matas representaria focos de doenças infecciosas. Tal permissividade de ocupação dos morros pelo Estado, que inclusive era proprietário de grande parte destas terras, intencionava a resolução rápida do deslocamento das populações mais pobres para áreas mais escondidas da capital do Estado. Não seria exagero afirmarmos que as políticas públicas em Florianópolis incentivaram a formação de favelas, notadamente a partir da década de 1920 (DANTAS; VENDRAMINI, 2011, p. 161-162).

A população residente no município de Florianópolis cresce, portanto, do balanço destes movimentos externos e internos e do acúmulo destas contradições. Este crescimento é particularmente acelerado na segunda metade do século $\mathrm{XX}$, conforme pode ser visto no gráfico 1 .

Esse crescimento promoveu aceleração da segregação urbana na cidade, na medida em que impulsionou expansão da ocupação das áreas de encostas do perímetro central (o Maciço Central), e se deu em um contexto de opção exclusiva do acesso à ilha pela parte central, o que legou às gerações futuras condições precárias de mobilidade, não obstante os sucessivos aterramentos para construções viárias. Reforçando esta contradição, a veiculação de Floria-

\footnotetext{
Por segregação sócio-espacial, entendemos o resultado do controle, produção e consumo do espaço urbano realizados pelas classes dominantes na cidade. Tal controle, produção e consumo são possíveis apenas com a concentração das classes subalternas em espaços localizados distantes dos centros urbanos que, segundo Villaça (1978; 2001), perpassam uma esfera econômica, uma esfera política e, por fim, uma esfera de produção de ideologia sobre o espaço urbano.
} 
nópolis como "cidade-mercadoria" privilegiou os balneários em detrimento do centro da cidade. Dada a distância física dos balneários e os núcleos de povoamento, característicos da cidade, esta opção indicou um terreno fértil para o modelo de mobilidade privado, através sobretudo de automóveis, e abriu uma perspectiva de valorização fundiária de extensas áreas localizada nos entornos dos acessos viários.

Gráfico 1 - População residente no município de Florianópolis - SC (1872 - 2010) Fonte: IBGE, 2010

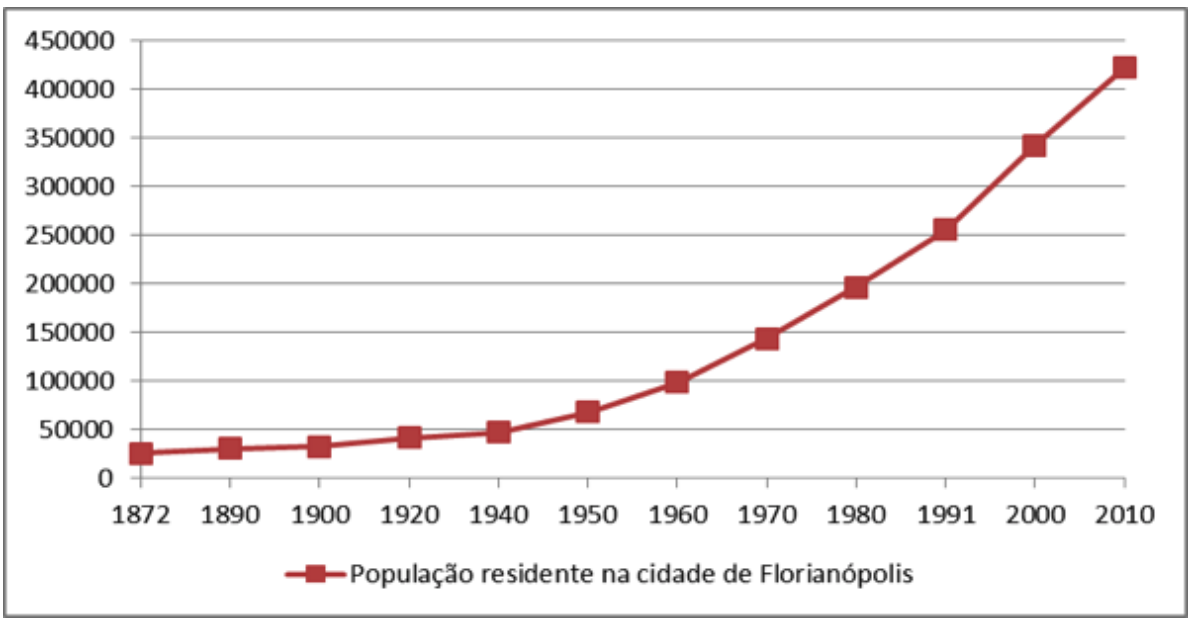

\section{As condições históricas da luta por moradia}

A constituição de Florianópolis como cidade-mercadoria é expressão de um processo mais geral por que passa o solo urbano nesta e em outras cidades regidas pela urbanização capitalista: a transformação da terra urbana de espaço da produção de valor para objeto da valorização do capital. Este processo assume particularidades no âmbito do capitalismo dependente, no qual Florianópolis naturalmente se insere, e promove importantes fissuras de classe horizontais (o projeto elitista de cidade2, que segrega a população economicamente subalterna) e verticais (a hegemonia da fração especulativa do capital, que se apoderará do espaço urbano e constrangerá as possibilidades de desenvolvimento industrial na cidade).

Não é, portanto, um fenômeno recente: no início da década de 1980, revistas de circulação nacional, especialmente a revista Visão, promoviam a di-

\footnotetext{
$2 \quad$ Categorias êmicas de movimentos sociais e organizações políticas de reforma urbana, como "projeto elitista de cidade", serão utilizadas em negrito ao longo deste texto.
} 
vulgação de Florianópolis como uma cidade segura3 e a sua diferenciação de outras capitais brasileiras, especialmente em termos de violência urbana e belezas naturais. A produção desta cidade-mercadoria evoluiu e refinou suas técnicas de propaganda e city-marketing4, apropriando-se, seja para ocultar, seja para deformar, de aspectos culturais locais. A chamada "vocação" turística (REIS, 2012), evocada e publicada nacionalmente, depara-se, por sua vez, com uma condição precária de mobilidade urbana e apropriação coletiva do espaço. Esta contradição revela que o turismo em si, e a cidade em termos mais gerais, possuem seletividades de classe: as belezas naturais são desfrutadas por poucos, a cidade apenas pertence aos que a trafegam em automóveis.

\begin{abstract}
A cidade passou progressivamente a ser moldada em duas dimensões interpretadas como as principais: a veicular e a de destino turístico, focando-se em atender o deslocamento eminentemente por automóvel, forjando uma lógica de planejamento como sinônimo de construção, abertura ou melhoria de estradas. Pelas estradas se pretendia chegar aos recursos, particularmente, às praias e localidades do interior da Ilha com paisagens que conquistavam catarinenses e turistas que vinham justamente para 'desbravar' esse paraíso cantado no hino de um pedacinho de terra que deixava de ser perdido e se encontrava em busca da inserção numa lógica maior de mercado (MARTINELLO; LENZI, 2011, p. 195).
\end{abstract}

De modo que o crescimento populacional de Florianópolis, associado à apropriação do espaço pelos grupos econômicos vinculados à especulação imobiliária e ao setor de turismo, se dá em um contexto de segregação sócio-espacial, espoliação urbana e super-exploração da força de trabalho (KOVARICK, 1980; MARINI; TRASPASDINI; STEDILE, 2005). Estes três pontos associam-se entre si e promovem uma alteração na dinâmica urbana da cidade: o crescente processo de periferização, não apenas nas encostas dos morros, como também horizontal, ou seja, a expansão da ocupação de áreas ainda mais isoladas do centro urbano, nas periferias de São José e de Palhoça, especialmente.

Este processo está diretamente associado com a atração populacional exercida pela cidade-mercadoria. Associa-se ainda, de forma complementar, a um conjunto de expulsões populacionais em cidades especialmente das mesorregiões Oeste e Serrana, e de Estados como Paraná, São Paulo e Rio Grande do Sul.

\footnotetext{
3 Matéria intitulada “Florianópolis. Lugar seguro: apenas um assalto em 1980”. Revista Visão, 23 de Fevereiro de 1981.

São comuns os ranqueamentos de cidades turísticas no mundo. Em um deles, a "cidade-mercadoria" Florianópolis foi vendida ao mundo inteiro através de anúncio em reportagem do jornal New York Times, na edição do dia 08 de Janeiro de 2009. Disponível em http://www.nytimes.com/2009/01/11/travel/11party.html? r $=0$
} 
No que se refere às migrações internas no estado de Santa Catarina, ressalta-se, sobretudo, a importância de dois processos regionais de expulsão populacional: na Mesorregião Oeste, em que o sistema da agroindústria gerou pressões sobre pequenos agricultores e concentrou a posse da terra na região; e na Mesorregião Sul, em que a crise no Complexo Carbonífero Sul-Catarinense, principal estrutura produtiva da região, liberou trabalhadores que não foram integralmente absorvidos pelos demais setores. Esses processos, que se desenvolvem desde o final da década de 1980 e atingem seu ápice na passagem do século XX ao XXI, expulsam contingentes populacionais que se dirigem, sobretudo, à Mesorregião da Grande Florianópolis. Mas não é apenas destas duas regiões que a "cidade-mercadoria" atrai população: grandes regiões mais distantes no Brasil, como o Norte e o Nordeste, também se constituem, nas últimas duas décadas, como polos de origem da imigração em Santa Catarina.

Vale ressaltar que esta migração interestadual se insere em um contexto de consolidação de Santa Catarina enquanto polo de atração populacional regional (em relação aos demais estados da região Sul do país); nacional (em relação aos Estados das outras grandes regiões brasileiras); e mesmo internacional (como demonstram os recentes fluxos de haitianos, ganeses e senegaleses, especialmente nas mesorregiões do Vale do Itajaí, do Sul catarinense e do Oeste Catarinense, mas que, exatamente por serem recentes, não foram registrados pelo último Censo Demográfico brasileiro, de 2010).

Tabela 1 - População residente em Santa Catarina segundo Estado e grande região de origem $(1991-2010)$

\begin{tabular}{lcccccc}
\hline & $\mathbf{1 9 9 1}$ & $\mathbf{2 0 0 0}$ & $\mathbf{2 0 1 0}$ & $\begin{array}{c}\mathbf{\%} \mathbf{1 9 9 1 -} \\
\mathbf{2 0 0 0}\end{array}$ & $\begin{array}{c}\mathbf{\% 2 0 0 0 -} \\
\mathbf{2 0 1 0}\end{array}$ & $\begin{array}{c}\mathbf{\%} \mathbf{1 9 9 1 -} \\
\mathbf{2 0 1 0}\end{array}$ \\
\hline Total & $\mathbf{4 . 5 4 2 . 0 3 2}$ & $\mathbf{5 . 3 5 7 . 8 6 4}$ & $\mathbf{6 . 2 4 8 . 4 3 6}$ & $\mathbf{1 7 , 9 6}$ & $\mathbf{1 6 , 6 2}$ & $\mathbf{3 7 , 5 7}$ \\
\hline $\begin{array}{l}\text { Região } \\
\text { Norte }\end{array}$ & $\mathbf{2 . 5 5 0}$ & $\mathbf{5 . 5 3 4}$ & $\mathbf{1 2 . 9 8 8}$ & $\mathbf{1 1 7 , 0 2}$ & $\mathbf{1 3 4 , 6 9}$ & $\mathbf{4 0 9 , 3 3}$ \\
\hline Rondônia & 687 & 1.798 & 2.804 & 161,72 & 55,95 & 308,15 \\
\hline Acre & 130 & 300 & 529 & 130,77 & 76,33 & 306,92 \\
\hline Amazonas & 430 & 565 & 1.335 & 31,40 & 136,28 & 210,47 \\
\hline Roraima & 79 & 198 & 2.082 & 150,63 & 951,52 & 2535,44 \\
\hline Pará & 1.111 & 2.405 & 5.275 & 116,47 & 119,33 & 374,80 \\
\hline Amapá & 76 & 66 & 228 & $-13,16$ & 245,45 & 200,00 \\
\hline Tocantins & 37 & 202 & 736 & 445,95 & 264,36 & 1889,19 \\
\hline $\begin{array}{l}\text { Região Nor- } \\
\text { deste }\end{array}$ & $\mathbf{1 2 . 8 0 3}$ & $\mathbf{2 5 . 6 1 5}$ & $\mathbf{5 9 . 2 7 3}$ & $\mathbf{1 0 0 , 0 7}$ & $\mathbf{1 3 1 , 4 0}$ & $\mathbf{3 6 2 , 9 6}$ \\
\hline Maranhão & 627 & 1.348 & 4.670 & 114,99 & 246,44 & 644,82 \\
\hline
\end{tabular}




\begin{tabular}{|c|c|c|c|c|c|c|}
\hline Piauí & 565 & 1.199 & 3.804 & 112,21 & 217,26 & 573,27 \\
\hline Ceará & 3.057 & 6.189 & 11.319 & 102,45 & 82,89 & 270,26 \\
\hline $\begin{array}{l}\text { Rio Gde do } \\
\text { Norte }\end{array}$ & 891 & 1.654 & 2.980 & 85,63 & 80,17 & 234,46 \\
\hline Paraíba & 869 & 2.063 & 4.889 & 137,40 & 136,98 & 462,60 \\
\hline Pernambuco & 2.466 & 4.607 & 9.693 & 86,82 & 110,40 & 293,07 \\
\hline Alagoas & 628 & 1.560 & 4.227 & 148,41 & 170,96 & 573,09 \\
\hline Sergipe & 422 & 744 & 2.142 & 76,30 & 187,90 & 407,58 \\
\hline Bahia & 3.278 & 6.250 & 15.550 & 90,67 & 148,80 & 374,37 \\
\hline $\begin{array}{l}\text { Região Su- } \\
\text { deste }\end{array}$ & 55.382 & 94.522 & 147.850 & 70,67 & 56,42 & 166,96 \\
\hline $\begin{array}{l}\text { Minas Ge- } \\
\text { rais }\end{array}$ & 7.749 & 12.310 & 20.118 & 58,86 & 63,43 & 159,62 \\
\hline $\begin{array}{l}\text { Espirito } \\
\text { Santo }\end{array}$ & 966 & 1.625 & 2.802 & 68,22 & 72,43 & 190,06 \\
\hline $\begin{array}{l}\text { Rio de Ja- } \\
\text { neiro }\end{array}$ & 12.621 & 18.621 & 25.535 & 47,54 & 37,13 & 102,32 \\
\hline São Paulo & 34.046 & 61.966 & 99.395 & 82,01 & 60,40 & 191,94 \\
\hline Região Sul & 4.454.629 & 5.205 .545 & 5.964 .062 & 16,86 & 14,57 & 33,88 \\
\hline Paraná & 172.208 & 278.729 & 411.178 & 61,86 & 47,52 & 138,77 \\
\hline $\begin{array}{l}\text { Santa Cata- } \\
\text { rina }\end{array}$ & 3.989 .677 & 4.585 .542 & 5.130 .746 & 14,94 & 11,89 & 28,60 \\
\hline $\begin{array}{l}\text { Rio Gde do } \\
\text { Sul }\end{array}$ & 292.744 & 341.273 & 422.139 & 16,58 & 23,70 & 44,20 \\
\hline $\begin{array}{l}\text { Região } \\
\text { Centro- } \\
\text {-Oeste } \\
\end{array}$ & 7.093 & 13.144 & 24.776 & 85,31 & 88,50 & 249,30 \\
\hline $\begin{array}{l}\text { Mato Grosso } \\
\text { do Sul }\end{array}$ & 1.632 & 4.382 & 9.909 & 168,50 & 126,13 & 507,17 \\
\hline Mato Grosso & 1.692 & 4.070 & 7.997 & 140,54 & 96,49 & 372,64 \\
\hline Goiás & 1.057 & 2.641 & 3.772 & 149,86 & 42,82 & 256,86 \\
\hline $\begin{array}{l}\text { Distrito Fe- } \\
\text { deral }\end{array}$ & 846 & 2.051 & 3.098 & 142,43 & 51,05 & 266,19 \\
\hline $\begin{array}{l}\text { Brasil sem } \\
\text { especifica- } \\
\text { ção }\end{array}$ & 1.866 & 946 & 21.864 & $-49,30$ & 2211,21 & 1071,70 \\
\hline $\begin{array}{l}\text { País estran- } \\
\text { geiro }\end{array}$ & 19.150 & 12.559 & 17.622 & $-34,42$ & 40,31 & $-7,98$ \\
\hline
\end{tabular}


Como indica a Tabela 1, há significativos incrementos da população residente em Santa Catarina cuja localidade de origem são os Estados da Região Norte, Nordeste e Centro-Oeste.

Da região Norte, destaca-se o crescimento do volume de pessoas residentes em Santa Catarina, porém nascidas no Pará (crescimento de 374,8\%) entre os anos de 1991 e 2010. Também a população residente nascida em Rondônia passou por elevado crescimento de seu volume, de 308,15\% no mesmo período analisado. Embora seja a grande região com menor população residente em Santa Catarina (12.988 pessoas segundo o Censo Demográfico de 2010), é a região de origem que obteve os maiores crescimentos nos três intervalos analisados: entre 1991 e 2000, entre 2000 e 2010 e, em conjunto, entre 1991 e 2010.

Da região Nordeste, por seu turno, destaca-se o crescimento da população residente em Santa Catarina de origem maranhense e piauiense (crescimentos totais de $644,82 \%$ e $573,27 \%$, respectivamente). É importante destacar, por outro lado, que os Estados da Bahia, Ceará e Pernambuco (respectivamente, primeiro, segundo e terceiro estados da região Nordeste com mais migrantes residentes em Santa Catarina), mesmo possuindo volumes populacionais residentes em Santa Catarina superiores aos demais estados da Região Nordeste, também obtiveram significativos crescimentos em seu volume, não apenas entre 1991 e 2010, como também entre 2000 e 2010, o período mais recente, o que indica a continuidade deste fluxo migratório originado nestes Estados rumo a Santa Catarina.

O crescimento nos volumes de população residente em Santa Catarina nascida nos Estados da Região Nordeste indica que a região nordestina continua, pelo menos em relação à Santa Catarina, a constituir-se enquanto fornecedora de força de trabalho, localizada em um contexto de produção de uma superpopulação relativa que, não obstante a melhoria dos indicadores sociais e econômicos na região, e inclusive a existência de um migração de retorno desde o Sudeste do país, permanece buscando novas e melhores oportunidades de vida em outras regiões do país. Na região Nordeste como um todo, e em sete dos seus nove estados, o crescimento dessa participação na população residente em Santa Catarina foi maior entre 2000 e 2010 do que entre 1991 e 2000 , indicando se tratar de um processo ainda em curso.

No que se refere à região Sudeste, percebe-se a posição de destaque ocupada pelo estado de São Paulo, o qual possui não apenas o maior volume da região em termos de migração para Santa Catarina, como também o maior crescimento deste volume entre 1991 e 2010. Segundo o Censo Demográfico de 2010 (IBGE, 2010 ), são 99.395 pessoas que vivem em Santa Catarina nascidas em São Paulo, volume apenas inferior ao representado pelos estados do Paraná (411.178 para- 
naenses que vivem em Santa Catarina), e do Rio Grande do Sul (422.139 pessoas nascidas no Rio Grande do Sul que, quando da aplicação do questionário do Censo Demográfico de 2010, declararam viver em Santa Catarina).

Da região Centro-Oeste, por fim, percebe-se o grande crescimento do fluxo sul-mato-grossense à Santa Catarina durante este período analisado. De segundo maior contingente, em 1991, passa a ser primeiro, já em 2000, e consolida sua posição no Censo de 2010. Entre 1991 e 2010, a presença de população nascida em Mato Grosso do Sul e residente em Santa Catarina cresce $507,17 \%$. Assim como nos demais estados desta região, esse crescimento se concentra mais entre 1991 e 2000 do que entre 2000 e 2010.

Tabela 2 - População residente segundo condição de naturalidade em relação ao município e ao Estado de Santa Catarina (2010)

\begin{tabular}{lcc}
\hline Estado/Município & $\begin{array}{c}\text { População residente } \\
\text { (Pessoas) }\end{array}$ & $\begin{array}{c}\text { População residente } \\
\text { (Percentual) }\end{array}$ \\
\hline Santa Catarina & $\mathbf{6 . 2 4 8 . 4 3 6}$ & $\mathbf{1 0 0}$ \\
\hline Naturais do município & 3.398 .503 & 54,39 \\
\hline Não naturais do município & 2.849 .933 & 45,61 \\
\hline Naturais da unidade da federação & 5.130 .746 & 82,11 \\
\hline Não naturais da unidade da federação & 1.117 .690 & 17,89 \\
\hline Biguaçu & $\mathbf{5 8 . 2 0 6}$ & $\mathbf{1 0 0}$ \\
\hline Naturais do município & 33.540 & 57,62 \\
\hline Não naturais do município & 24.666 & 42,38 \\
\hline Naturais da unidade da federação & 50.764 & 87,21 \\
\hline Não naturais da unidade da federação & 7.442 & 12,79 \\
\hline Florianópolis & $\mathbf{4 2 1 . 2 4 0}$ & $\mathbf{1 0 0}$ \\
\hline Naturais do município & 201.421 & 47,82 \\
\hline Não naturais do município & 219.819 & 52,18 \\
\hline Naturais da unidade da federação & 293.262 & 69,62 \\
\hline Não naturais da unidade da federação & 127.978 & 30,38 \\
\hline Palhoça & $\mathbf{1 3 7 . 3 3 4}$ & $\mathbf{1 0 0}$ \\
\hline Naturais do município & 58.608 & 42,68 \\
\hline Não naturais do município & 78.726 & 57,32 \\
\hline Naturais da unidade da federação & 118.894 & 86,57 \\
\hline Não naturais da unidade da federação & 18.440 & 13,43 \\
\hline
\end{tabular}




\begin{tabular}{lcc}
\hline São José & $\mathbf{2 0 9 . 8 0 4}$ & $\mathbf{1 0 0}$ \\
\hline Naturais do município & 8.1708 & 38,95 \\
\hline Não naturais do município & 128.096 & 61,05 \\
\hline Naturais da unidade da federação & 173.751 & 82,82 \\
\hline Não naturais da unidade da federação & 36.053 & 17,18 \\
\hline
\end{tabular}

Fonte: IBGE, 2010

Como se pode ver na Tabela 2, o município de Florianópolis possui percentuais próximos ao estadual e aos de municípios vizinhos (São José, Palhoça e Biguaçu) em termos de população residente que não é natural do município; ou seja, que nasceu em qualquer outro município, inclusive da mesma Unidade da Federação. O percentual de Florianópolis é de 52,18\%. Os percentuais das quatro cidades estão localizados entre $42,38 \%$ (referente à Biguaçu), e 61,05\% (referente à São José). Todavia, quando analisamos os dados relativos à população residente não natural da unidade da federação, percebemos uma importante especificidade do município de Florianópolis: a capital possui percentual de sua população não nascida no estado de Santa Catarina significativamente superior ao percentual catarinense e dos municípios vizinhos: $30,38 \%$. Adiciona-se a isto que $52,18 \%$ da população residente neste município não é natural de Florianópolis.

O também elevado percentual de pessoas não naturais do município em que residem, em São José e Palhoça, indica outro fenômeno relacionado ao processo migratório, à especulação imobiliária e à periferização urbana horizontal, qual seja, a intensificação da mobilidade intraurbana como promotora da expansão da ocupação das periferias das cidades de São José e Palhoça.

A elevação da renda da terra em Florianópolis provoca crescimento do valor dos aluguéis e encarecimento do preço dos imóveis e terrenos urbanos. Essas transformações são produzidas na amplitude da cidade e adquirem caráter de contradição social e econômica (a remuneração da classe trabalhadora não permite o pagamento destes custos e o atendimento das outras necessidades de reprodução do valor desta força de trabalho) à medida que a fração imobiliária do capital e sua incipiente integração financeira dominam a economia local. Dizer que o capital especulativo, imobiliário, encontra-se em posição de hegemonia no sistema capitalista total da cidade significa considerar que esta fração do capital organiza não só as demais frações, como também o próprio processo de produção de valor na região, condicionando as esferas governamentais a orientarem recursos a seus negócios (seja pela exigência econômica 
e política de infraestrutura a seus empreendimentos, seja pelas formas ilegais com que grupos empresariais apropriam-se de recursos públicos na história recente da cidades).

O chamado "projeto elitista de cidade" é o resultado dessas contradições geradas historicamente. Ele atua como verdadeiro fator de "despejo branco" na cidade, pressionando parte da população a transferir sua residência para os municípios vizinhos. A mobilidade intraurbana na região se dá expulsando os setores sociais mais vulneráveis da ilha ao continente, impactando o crescimento demográfico em Florianópolis inferior, nas últimas décadas, à região mais periférica da Grande Florianópolis (Palhoça e Biguaçu), conforme se pode observar na Tabela 3.

Tabela 3 - População residente e crescimento demográfico nas principais cidades da Grande Florianópolis (1991 - 2010)

\begin{tabular}{lcccccc}
\hline & \multirow{2}{*}{$\mathbf{1 9 9 1}$} & $\mathbf{2 0 0 0}$ & $\mathbf{2 0 1 0}$ & $\mathbf{2 0 0 0}$ & $\mathbf{2 0 1 0}$ & $\mathbf{2 0 1 0}$ \\
\hline Santa Catarina & 4.542 .048 & 5.357 .864 & 6.248 .436 & 17,96 & 16,62 & 37,57 \\
\hline Biguaçu - SC & 34.063 & 48.077 & 58.206 & 41,14 & 21,07 & 70,88 \\
\hline $\begin{array}{l}\text { Florianópolis- } \\
\text { SC }\end{array}$ & 255.389 & 342.315 & 421.240 & 34,04 & 23,06 & 64,94 \\
\hline Palhoça - SC & 68.430 & 102.742 & 137.334 & 50,14 & 33,67 & 100,69 \\
\hline São José - SC & 139.493 & 173.559 & 209.804 & 24,42 & 20,88 & 50,40 \\
\hline
\end{tabular}

Fonte: IBGE, 2010

A pressão por que passa esta população para transferir sua residência a espaços mais distantes do centro urbano e diminuir, com isto, seus gastos com moradia aprofunda um elemento essencial da espoliação urbana: o distanciamento entre o local de residência e o local de trabalho. Segundo a Tabela 4, no ano de 2010, 39,72\% do pessoal ocupado em Biguaçu trabalhava em outro município. Este percentual foi de 38,34\% em Palhoça e de 35,35\% em São José. Em Florianópolis, apenas $6,84 \%$ do pessoal ocupado trabalha em outro município.

A Operação Moeda Verde, por exemplo, foi deflagrada pela Polícia Federal em 2007, para investigar, julgar e prender envolvidos (empresas, funcionários públicos, vereadores e deputados) em esquema de falsificação de laudas ambientais, vendas de licenças ambientais e tráfico de influência para a construção de empreendimentos (residenciais, comerciais e, sobretudo, turísticos) em áreas irregulares, especialmente de mangue. (cf. TORTATO, Mari, 2007). 
Tabela 4 - Município de residência e município de trabalho do pessoal ocupado nas principais cidades da Grande Florianópolis (2010)

\begin{tabular}{|c|c|c|}
\hline Município & Pessoal ocupado & $\begin{array}{c}\text { Pessoal ocupado } \\
(\%) \\
\end{array}$ \\
\hline Biguaçu & 29.643 & 100 \\
\hline Município de residência & 17.527 & 59,13 \\
\hline $\begin{array}{l}\text { Município de residência - no domicílio de re- } \\
\text { sidência }\end{array}$ & 6.403 & 21,6 \\
\hline $\begin{array}{l}\text { Município de residência - fora do domicílio } \\
\text { de residência }\end{array}$ & 11.125 & 37,53 \\
\hline Outro município & 11.773 & 39,72 \\
\hline País estrangeiro & 4 & 0,01 \\
\hline Mais de um município ou país & 338 & 1,14 \\
\hline $\begin{array}{r}\text { Florianópolis } \\
\end{array}$ & 229.002 & 100 \\
\hline Município de residência & 210.461 & 91,9 \\
\hline $\begin{array}{l}\text { Município de residência - no domicílio de re- } \\
\text { sidência }\end{array}$ & 39.404 & 17,21 \\
\hline $\begin{array}{l}\text { Município de residência - fora do domicílio } \\
\text { de residência }\end{array}$ & 171.057 & 74,7 \\
\hline Outro município & 15.673 & 6,84 \\
\hline País estrangeiro & 161 & 0,07 \\
\hline Mais de um município ou país & 2.708 & 1,18 \\
\hline $\begin{array}{r}\text { Palhoça } \\
\end{array}$ & 74.774 & 100 \\
\hline Município de residência & 43.556 & 58,25 \\
\hline $\begin{array}{l}\text { Município de residência - no domicílio de re- } \\
\text { sidência }\end{array}$ & 12.598 & 16,85 \\
\hline $\begin{array}{l}\text { Município de residência - fora do domicílio } \\
\text { de residência }\end{array}$ & 30.958 & 41,4 \\
\hline Outro município & 28.666 & 38,34 \\
\hline País estrangeiro & 14 & 0,02 \\
\hline Mais de um município ou país & 2.538 & 3,39 \\
\hline São José & 117.247 & 100 \\
\hline Município de residência & 73.180 & 62,42 \\
\hline $\begin{array}{l}\text { Município de residência - no domicílio de re- } \\
\text { sidência }\end{array}$ & 15.478 & 13,2 \\
\hline $\begin{array}{l}\text { Município de residência - fora do domicílio } \\
\text { de residência }\end{array}$ & 57.703 & 49,21 \\
\hline
\end{tabular}




\begin{tabular}{lcc}
\hline Outro município & 41.449 & 35,35 \\
\hline País estrangeiro & 7 & 0,01 \\
\hline Mais de um município ou país & 2.610 & 2,23 \\
\hline
\end{tabular}

Fonte: IBGE, 2010.

Esse distanciamento entre o local de residência e o local de trabalho adquire proporções dramáticas na medida em que o acesso entre as cidades da Grande Florianópolis passa ou cruza a malha rodoviária federal (BR-101, BR - 282 e BR 283), de modo que à distância espacial entre as cidades adiciona-se ainda o tempo gasto de deslocamento entre a residência e o trabalho em condições de constante tráfego e engarrafamento. Esse tempo se dá em função do trabalho e corresponde, por consequência, a uma parcela do tempo de reprodução da classe trabalhadora que não é paga, e que viola, portanto, o valor da força de trabalho. Trata-se de uma modalidade bastante atual embora ainda pouco compreendida da superexploração da força de trabalho.

Tabela 5 - Tempo de deslocamento entre o domicílio e o local de trabalho das principais cidades da Grande Florianópolis (2010)

\begin{tabular}{lcc}
\hline \multicolumn{1}{c}{ Município } & Pessoal ocupado & Pessoal ocupado (\%) \\
\hline Biguaçu & 22.218 & 100 \\
\hline Até cinco minutos & 1.709 & 7,69 \\
\hline De seis minutos até meia hora & 11.352 & 51,09 \\
\hline Mais de meia hora até uma hora & 7.589 & 34,15 \\
\hline Mais de uma hora até duas horas & 1.450 & 6,53 \\
\hline Mais de duas horas & 119 & 0,54 \\
\hline \multicolumn{1}{c}{ Florianópolis } & 180.732 & 100 \\
\hline Até cinco minutos & 17.422 & 9,64 \\
\hline De seis minutos até meia hora & 103.807 & 57,44 \\
\hline Mais de meia hora até uma hora & 44.741 & 24,76 \\
\hline Mais de uma hora até duas horas & 13.603 & 7,53 \\
\hline Mais de duas horas & 1.159 & 0,64 \\
\hline \multicolumn{1}{c}{ Palhoça } & 56.781 & 100 \\
\hline Até cinco minutos & 5.490 & 9,67 \\
\hline De seis minutos até meia hora & 28.812 & 50,74 \\
\hline Mais de meia hora até uma hora & 16.592 & 29,22 \\
\hline
\end{tabular}




\begin{tabular}{lcc}
\hline Mais de uma hora até duas horas & 5.538 & 9,75 \\
\hline Mais de duas horas & 350 & 0,62 \\
\hline \multicolumn{1}{c}{ São José } & 96.435 & 100 \\
\hline Até cinco minutos & 8.094 & 8,39 \\
\hline De seis minutos até meia hora & 55.028 & 57,06 \\
\hline Mais de meia hora até uma hora & 277.47 & 28,77 \\
\hline Mais de uma hora até duas horas & 5.265 & 5,46 \\
\hline Mais de duas horas & 302 & 0,31 \\
\hline
\end{tabular}

Fonte: IBGE, 2010.

Considerando que a Tabela 5 refere-se ao tempo de deslocamento apenas entre a residência e o local de trabalho, o mais adequado para se pensar em termos de apropriação do tempo de trabalho e de violação do seu valor seria dobramos esse tempo, pois desde que sai de sua casa até o momento em que a ela retorna, o trabalhador está envolvido e em função da sua jornada diária de trabalho. Assim sendo, percebe-se que a maior parte do pessoal ocupado nestas cidades leva de 12 minutos a uma hora de deslocamento (51,09\% em Biguaçu; 57,44\%, em Florianópolis; 50,74\%, em Palhoça; e 57,06\%, em São José). E de uma hora a duas horas de deslocamento (34,15\%, em Biguaçu; $24,76 \%$, em Florianópolis; 29,22\%, em Palhoça; e 28,77\%, em São José). Chama a atenção que quase $10 \%$ do pessoal ocupado de Palhoça dispende, diariamente, entre duas até quatro horas no deslocamento em função do trabalho.

O local da moradia está no cerne das contradições apontadas até o momento: é sua localização que condicionará o valor do aluguel, a satisfação das demais necessidades envolvidas na reposição do desgaste da força de trabalho, as possibilidades de aquisição da casa própria, a distância entre a casa e o trabalho e o tanto do valor da força de trabalho que será violado e apropriado no tempo de deslocamento entre a casa e o trabalho. Sob um projeto elitista de cidade em curso, estes elementos têm sido depreciados, ocasionando uma elevação da espoliação urbana e da superexploração da força de trabalho.

De outro lado, as possibilidade de financiamento estatal da moradia própria, através, sobretudo do Programa Minha Casa Minha Vida, além de não conferirem prioridade às camadas mais subalternas (na linguagem e metodologia do Programa, as chamadas classes de rendimento de 0 a 3 salários mínimos, a maior parte do déficit habitacional existente), ainda conferem às construtoras o poder de definição da localização dos imóveis. Com isto, mais que resolver, agrava os problemas elencados acima. A produção das contradições urbanas tem sido, então, a produção mesma dos fatores que põem a mobilidade humana a serviço do projeto capitalista de cidade. A luta pela mo- 
radia, dado que perpassa a luta pela mobilidade, é em essência uma luta contra este modelo de cidade.

\section{A Ocupação Contestado e a luta por moradia}

Fruto das contradições acima expostas, a Ocupação expressa em suas origens a participação direta que, como vimos, o poder público tem na viabilização de ocupações irregulares e no processo de periferização, "limpando" as áreas centrais das cidades brasileiras de uma população indesejada. Nesta seção, iremos compor uma breve narrativa do processo de criação e consolidação da Ocupação Contestado, buscando teorizar sua história recente à luz das contradições urbanas da região da Grande Florianópolis.

Em atividade de campanha para a sua reeleição à prefeitura de São José, o então prefeito da cidade, Djalma Berger, recebe seu irmão, Dário Berger, então prefeito de Florianópolis, no palanque de um comício realizado na região do José Nitro, em São José. Em sua fala aos presentes no comício, Dário Berger sentencia e promete:

\footnotetext{
Hoje os companheiros estão com uma ordem de despejo, uma ordem judicial de despejo. Então a partir já de setembro, como foi assinado o decreto, essa possibilidade de despejo, ela não existe mais (pausa para aplausos e comemoração dos presentes ao comício). Portanto, a prefeitura vai indenizar o terreno, vai legalizar o terreno e vai dar o terreno para os proprietários que estão em cima do terreno ali da Imobiliária Suvec (mais aplausos e comemoração dos presentes) (CMI, 2012).
}

O comício foi realizado poucos dias antes das eleições municipais, realizadas a 7 de outubro de 2012. Após os discursos e promessas de campanha, mais de cem famílias passam a ocupar o terreno indicado, localizado às margens da Avenida das Torres, na região de São José conhecida como José Nitro. Vendem pertences, assumem dívidas e saem de sua moradia anterior - de aluguel ou de favor, na maioria dos casos - e constroem na terra prometida a primeira versão de sua moradia própria: barracos de lona, alguns com armação em madeira, feitos de sobras de material de outras construções.

Nas urnas, todavia, o prefeito Djalma Berger não obteve sua reeleição: com $61,19 \%$ dos votos válidos, a candidata Adeliana Dal Pont (PSD) vence as eleições ainda no primeiro turno, contra $33,03 \%$ dos votos para Djalma Berger. Apenas três dias depois, em 10 de outubro, imensa operação policial mobiliza mais de 200 efetivos para dar cumprimento a uma ordem judicial de despejo daquelas mais de cem famílias que ocupavam o terreno prometi- 
do. Com denúncias de violência e cometimento de arbitrariedades contra os pertences dos moradores, a operação é realizada e, já nas primeiras horas da manhã daquele dia, as famílias são despejadas. A notícia do despejo ganhava as rádios locais. Militantes de diversas organizações, movimentos sociais e partidos políticos denunciavam a operação na internet. Em poucas horas, mediadores políticos e integrantes de uma futura rede de apoio chegam ao local do despejo e passam a contribuir nas primeiras ações de reorganização e remobilização das famílias, algumas já dispersadas.

A pressão juntos aos órgãos públicos municipais, especialmente aqueles vinculados à Secretaria de Assistência Social de São José, confere um primeiro resultado: a concessão do Ginásio Municipal do Jardim Zanellato para o abrigo provisório das famílias. Entre 10 de outubro e a madrugada do dia 07 de novembro de 2012, cerca de 80 famílias abrigam-se no Ginásio. No local, no entanto, ainda estavam permitidas realizações de partidas e campeonatos em sua quadra, inclusive durante a noite, o que ocasionou problemas de convivência; por outro lado, os abrigados sofriam com o fornecimento instável de água e a ausência de privacidade entre as famílias.

Durante 26 dias, formou-se uma rede de apoio aos abrigados, organizada sobretudo em torno a alguns sindicatos de trabalhadores e da associação docente da UDESC (subseção sindical do ANDES). Se a constituição dessa rede foi um passo essencial para a conscientização e sensibilização de setores sociais identificados com as lutas populares, formando estruturas de solidariedade, por outro, revelou limites, salvo raras experiências, de converter estes setores de apoiadores materiais em militantes do movimento. Essa dificuldade é expressão, por sua vez, de dois elementos: o desenvolvimento histórico de uma relação de solidariedade apenas vertical entre os setores envolvidos e a limitação do próprio movimento de luta por moradia em oferecer espaços e atuações orgânicos a estes setores.

Nestes mesmos dias, no entanto, a mediação política logrou construir junto aos abrigados uma direção política às reivindicações e uma articulação em torno à denúncia da responsabilidade do município com aquela situação, além da assessoria jurídica para os passos seguintes. Essa mediação, construída cotidianamente, consolidou-se sobretudo por conta da atuação de três organizações políticas: as Brigadas Populares de Santa Catarina (BPs - SC); o Coletivo Anarquista Bandeira Negra (CABN); e o Movimento dos SemTerra (MST). Estes grupos rapidamente perceberam a necessidade e importância de rearticular o movimento de luta por moradia na Grande Florianópolis, para além de sua institucionalização. Um primeiro fórum neste sentido foi realizado 03 de novembro na Universidade Federal de Santa Catarina (UFSC). A primeira tentativa de utilizar a experiência específica da Ocupa- 
ção Contestado, como forma de contribuição a um movimento mais geral de luta por moradia, logrou conquistar importantes apoiadores para a Ocupação. No futuro, esta tentativa seria fundamental para dar sequência ao ciclo de ocupações urbanas, colaborando de forma direta com a Ocupação Palmares e a Comuna Amarildo.

Ao longo daqueles 26 dias, o acúmulo das tensões entre os moradores, ocasionadas pelas péssimas condições de abrigo, mostrava que o instrumento da luta pela moradia não poderia se restringir apenas às reivindicações mais pontuais e à pressão institucional, mas que deveria, também, apontar para ações diretas, dentro ainda do marco da legalidade; porém, com maior capacidade de intervenção direta na apropriação do espaço. Este instrumento é a ocupação urbana.

Assim, na madrugada do dia 06 ao 07 de novembro de 2012, cerca de 80 famílias deslocam-se do Ginásio do bairro Jardim Zanellato, localizadado na rua Nossa Senhora dos Navegantes, até terreno próximo à rua Afrísio de Senna Vaz, no loteamento paralelo ao Jardim Zanellato, o Jardim Araucária. Do Ginásio, após 26 duros dias, à nova terra prometida, foi realizada uma caminhada de 900 metros de muito significado no contexto da retomada das ocupações urbanas organizadas na Grande Florianópolis.

Já na manhã em que se deu a ocupação, percebeu-se o enorme desafio organizacional: a lista de espera - fruto do enorme déficit habitacional na região - rapidamente pressionava por uma expansão do número de famílias. Com, então, 100 famílias, o espaço foi organizado em lotes, fração de terra destinada à construção das moradias, mas que não pertence ao morador e, simm ao conjunto da ocupação. Em outras palavras, não há donos individuais. A dificuldade de compreensão disto expressa uma contradição de nossa sociedade: educados e instruídos a acreditarem na legalidade da propriedade privada, não percebem criticamente que é justamente a propriedade privada e a mercantilização do direito de moradia que os condena a habitações precárias, imóveis de aluguel e moradia de favor, quando não, a rua. Por outro lado, sempre lutaram para sair desta condição por meio do acesso à propriedade privada! Desfazer este nó é necessariamente uma tarefa de formação: formação sobre as contradições e mitos da sociedade capitalista, e formação sobre o significado da reforma urbana e do sentido coletivo que a luta por moradia, via ocupação, impõe.

Os lotes, em conjunto, compõem a dinâmica de organização política das famílias. O primeiro nível de coletividade é o do núcleo. Um núcleo é definido pela proximidade espacial entre as casas. Cada núcleo é composto por pouco mais de dez casas. Há oito núcleos na Ocupação Contestado, são eles: Dandara, Vida Nova, Che Guevara, Zapata, Guerreiros de Fé, Mansidão, Es- 
trela-Guia e Anita Garibaldi. Cada núcleo possui um ou dois coordenadores e, semanalmente, ocorrem as reuniões de coordenação. São encontros em que são feitos repasses dos núcleos e resolvidos os principais problemas da Ocupação. Pela disposição do terreno e sua condição sanitária, há três quadras que podem ser ocupadas. Essa divisão espacial possibilitou a existência de um segundo nível de coletividade: o da quadra. As reuniões de quadra servem para discutir as questões estruturais do espaço, como as fossas, as reformas e a caixa de água. O terceiro nível de coletividade é o da assembleia, que envolve todos os moradores da Ocupação.

As assembleias têm sua frequência definida pela conjuntura política da Ocupação: em momentos de ameaça de despejo ou de organização de algum ato de protesto (marcha, ocupação simbólica de espaço público etc), elas são mais frequentes. Há, ainda, a possibilidade de assembleias extraordinárias, realizadas sempre que se faz necessário reunir o maior número possível de moradores para definir algo imediatamente. Ordinariamente, as assembleias definem aquilo que núcleos, quadras e reuniões de coordenação não têm autonomia para decidir: entradas e expulsões da ocupação. A convivência é mediada por um regimento interno, que estabelece, entre outras normas, a centralidade do debate para todas as decisões - e a rejeição ao emprego de qualquer forma de violência, em qualquer âmbito de convivência. Ocorrências desta natureza são levadas à discussão coletiva em assembleia e estão sujeitas à expulsão dos envolvidos da ocupação.

Toda esses instrumentos de organização interna da ocupação cumprem uma importante função política: ao democratizar e coletivizar ao máximo as decisões sobre a vida cotidiana dentro da ocupação e sobre as estratégias para a conquista da moradia, promove experiências efetivas de novas formas de poder. São pequenos embriões de poder popular que promovem alterações substantivas na consciência dos moradores.

Entre o final de novembro de 2012 e os primeiros dias de dezembro do mesmo ano, a Imobiliária Suvec entra na Justiça com uma liminar de reintegração de posse, exigindo o despejo das cerca de 100 famílias que ocupavam, há quase um mês, o novo terreno. Esta liminar recebe parecer favorável do Tribunal de Justiça de Santa Catarina. A rede de advogados é acionada e entra, imediatamente, com uma ação para tentar derrubar a liminar. Paralelamente, é lançada a campanha "Despejo Não! Contestado Vive”, que passa a envolver a opinião pública e denunciar a omissão do poder público com aquele conjunto de famílias. Nesse mesmo momento, os moradores começam a tomar consciência mais crítica dos problemas sociais e urbanos, envolvendo-se diretamente em momentos importantes da greve dos trabalhadores da saúde, das pressões e reivindicações dos trabalhadores do transporte público urbano 
e das paralisações dos trabalhadores de estabelecimentos bancários, fortalecendo os laços de cooperação e solidariedade horizontal com o setor sindical mais combativo.

O envolvimento da Superintendência do Patrimônio da União (SPU) no processo de discussão da proteção das famílias diante da ameaça real de despejo e sua inclusão em projetos de construção de habitação popular fez com que, após reunião deste órgão, realizada no dia 05 de novembro de 2012, a SPU emitisse um ofício ao Promotor de Justiça da Comarca de São José, Jadel da Silva Junior, solicitando o cumprimento de um Termo de Ajustamento de Conduta (TAC) em área da União para o acolhimento das famílias vítimas de ameaça de despejo. Nesse ofício, a SPU reporta-se ao promotor pedindo:

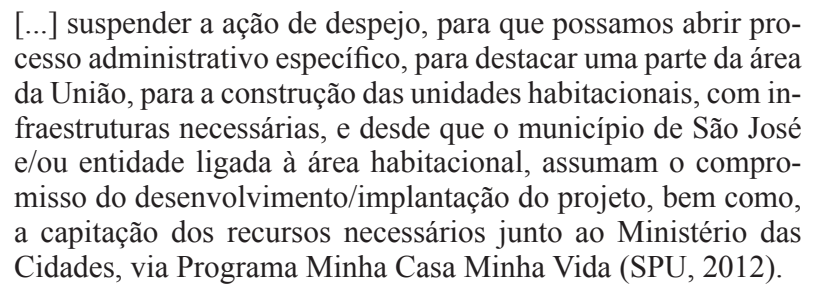

O ofício foi expedido no dia 06 de novembro. A ação de suspensão da liminar de despejo, por sua vez, fora analisada pelo Tribunal de Justiça de Santa Catarina no dia seguinte. No julgamento, realizado pelo desembargador Luiz Zanelato, ficou exposta a incapacidade jurídica de a Imobiliária Suvec e seus representantes comprovarem a posse legal do terreno e, apropriando-se de um contrato de compra e venda feito em nome de terceiro, o qual "de forma alguma se confunde com a referida imobiliária" (ZANELATO, 2012). O desembargador, diante da contradição jurídica afirmada acima, estabelece que:

[...] examinadas as provas carreadas aos autos, denota-se que
referidos elementos que serviram de alicerce à decisão impug-
nada, não se prestam, por si só, à demonstração dos requisitos
legais que fundamentam a concessão da sobredita medida. Isto
porque não revelam, de forma minimamente verossímil, a indi-
viduação da posse alegadamente esbulhada pelos réus da ação
possessória subjacente, porque não há vinculação entre os da-
dos contidos nos documentos apresentados aptos a comprovar
a correspondência entre o imóvel dito esbulhado e aquele sobre
o qual o agravado afirma ser o detentor da posse (DJSC, 2012).

De modo que sua decisão indica pela suspensão da liminar de reintegração de posse, comunicando "com urgência" este juízo, dado que as forças policiais e midiáticas estavam já a postos para o cumprimento do despejo que, como 
julgado, não tinha respaldo legal. Com esta primeira batalha jurídica sendo ganha para o movimento, o trabalho de base na Ocupação pôde ser aprofundado. Ao longo do ano de 2013, foram aprofundadas as negociações em torno ao projeto habitacional, possibilidade aberta pelo referido ofício da SPU. De igual modo, houve consolidação da rede de apoio, que passou a envolver ainda projetos de extensão universitária (nas áreas de saúde, economia e serviço social) e de educação de jovens e adultos.

No final de 2013, as comemorações do primeiro aniversário da Ocupação significaram um importante momento de avaliação dos rumos do movimento e da importância de sua luta no contexto das contradições urbanas e sociais da Grande Florianópolis. Na ocasião, foi produzido um jornal especial da comunidade, feita pelos moradores com auxilio da rede de apoio. As atividades de distribuição nas ruas do jornal e a festa de aniversário oferecida ao bairro em frente ao Ginásio tiveram um conteúdo político muito definido: os moradores apenas obtiveram vitórias porque estavam organizados.

Atualmente, a Ocupação Contestado luta para dar sequência à disputa pelo projeto habitacional: disputa porque as "ofertas" de aluguel social seguem sendo feitas, como mecanismo de enfraquecimento do movimento; disputa porque mesmo na negociação do projeto há tentativas de apropriação por terceiros de partes do terreno indicado pela SPU; disputa para que o projeto não seja realizado em áreas ainda mais distantes, sob alegação de que, por serem menos valorizadas, "cabem mais pessoas". Disputa para que o que se entende por "pessoas" não seja mais as classes subalternas, que devem morar sempre longe dos centros urbanos.

\section{A demografia social da Ocupação Contestado}

Nesta seção de nosso artigo, apresentaremos informações sociais, econômicas e demográficas da Ocupação Contestado. Estes dados foram levantados a partir da aplicação de survey em 82 casas da Ocupação Contestado'. Este survey, por sua vez, integra uma pesquisa mais ampla coordenada pelo professor Francisco Canella, da UDESC . O objetivo é caracterizar de forma mais precisa quem são os moradores da Ocupação ${ }^{8}$ e como suas características es-

\footnotetext{
Não foi possível aplicar questionário em 18 das 100 casas da Ocupação. A equipe de aplicação identificou estas casas e retornou a elas em horários diferentes do dia e em dias diferentes da semana, todavia sem sucesso.

Projeto de pesquisa "O movimento sem-teto e a Ocupação Contestado: perfil social e trajetórias de vida dos moradores" (CANELLA, Francisco, 2015)

Os questionários foram aplicados entre o final de 2013 e o início de 2014. As informações foram tratadas e tabuladas ao longo de 2014, até o mês de setembro, quando os resultados da aplicação do questionário foram fechados. Algumas variáveis referem-se ao universo dos moradores, enquanto outras aos responsáveis pelos domicílios. São mais de 150 variáveis. Em razão dos objetivos deste artigo e do limite de páginas, selecionamos apenas algumas variáveis, mais relacionadas ao escopo do texto.
} 
pecíficas relacionam-se com as contradições urbanas na Grande Florianópolis. Um objetivo específico é investigar mais a fundo sua mobilidade intra-urbana e trajetórias migratórias, buscando entendê-las à luz da dinâmica migratória e econômica catarinenses.

A população residente na Ocupação Contestado é de 245 pessoas, das quais 126 são homens (51,42\% da população total), e 119 são mulheres (48,57\% da população total). A estrutura etária desta população revela o predomínio de jovens e, principalmente, de crianças, em idade entre 0 a 14 anos. Sua forma piramidal, ainda que com entradas e instabilidades características de uma população pequena, denota se tratar de uma população que ainda não passou pela transição demográfica, ou seja, permanece com altas taxas de mortalidade e de fecundidade e baixa participação da população idosa na população total.

Gráfico 2 - Estrutura etária dos moradores da Ocupação Contestado

Fonte: Dados levantados pelos autores (In: CANELLA, 2015)

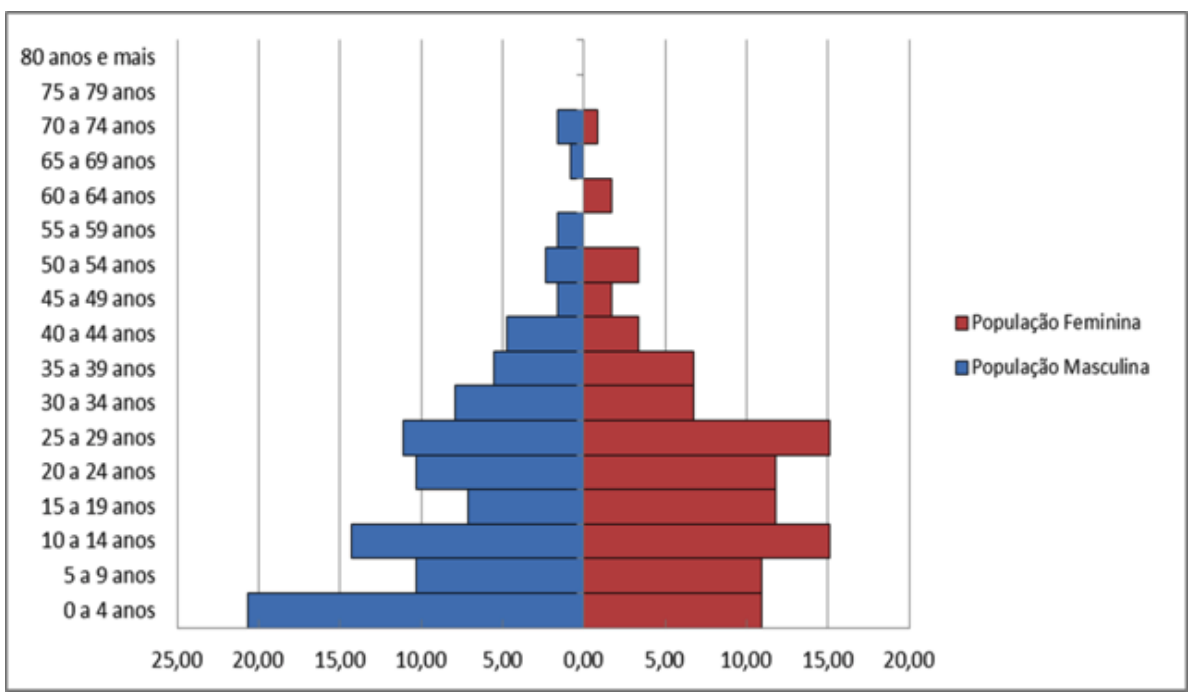

Como analisado anteriormente, a Ocupação Contestado é fruto das contradições urbanas que segregam espacialmente e criam as condições para o movimento de luta por moradia - justamente porque negam moradia a amplas parcelas da população. A maioria dos moradores da Ocupação Contestado residia anteriormente em casas alugadas ( $76,6 \%$ das famílias), ao passo em que $21,3 \%$ das famílias morava de favor. Nenhuma família possuía casa própria, e 2,1\% das famílias morava em "outra situação". Quando perguntado qual era esta "outra situação", os responsáveis pelos domicílios responderam que eles e as suas famílias era moradores de rua. 
Gráfico 3 - Situação da moradia anterior

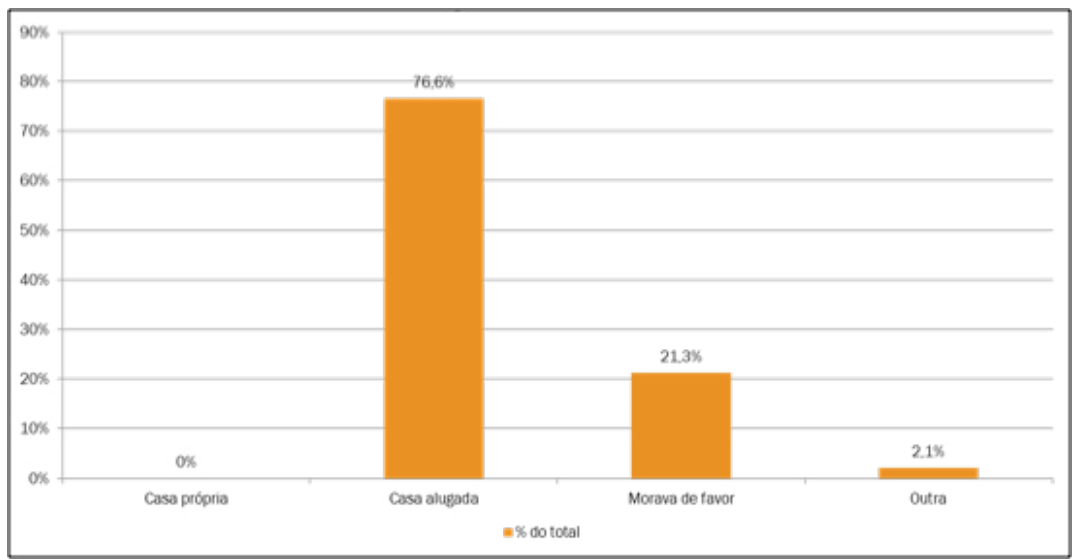

Fonte: Dados levantados pelos autores (In: CANELLA, 2015)

A ocupação, para as famílias que nela residem, significou não ter mais de pagar aluguel mensalmente, poder sair de um cômodo em que habitavam de favor e mesmo poder sair das ruas. A maior parte destas famílias, como revela o Gráfico 4, morava sobretudo no próprio município de São José $(63,41 \%$ do total). Mais de um terço destas famílias, no entanto, tiveram como última residência, antes da Ocupação, municípios vizinhos situados na Grande Florianópolis (como Biguaçu, Florianópolis, Palhoça, Governador Celso Ramos, Porto Belo e São João Batista), e municípios mais distantes, como Itajaí (na mesorregião do Vale do Itajaí) e Laguna (na mesorregião Sul Catarinense).

Gráfico 4 - Município de residência anterior das famílias da Ocupação Contestado

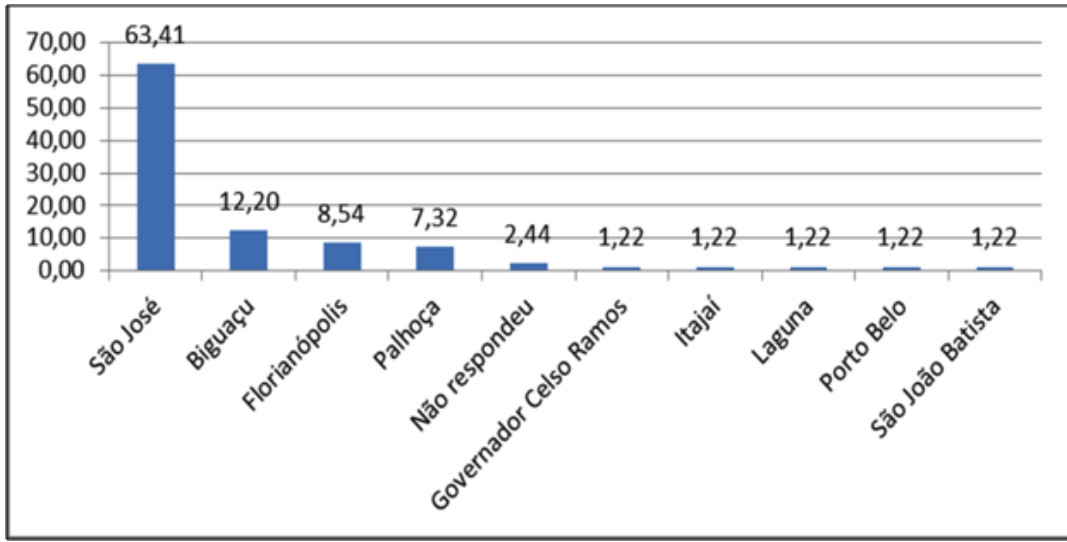

Fonte: Dados levantados pelos autores (In: CANELLA, 2015) 
Dado que maior parte dos moradores da Ocupação Contestado residissem anteriormente no próprio município de São José, os principais bairros de residência anterior localizam-se neste município. Quando perguntados em que bairro residiam com suas famílias imediatamente antes de mudarem para a Ocupação, indicaram bairros muito próximos, conforme pode ser visto no Gráfico 5.

Gráfico 5 - Bairro de residência anterior à Ocupação Contestado (dez principais resultados)

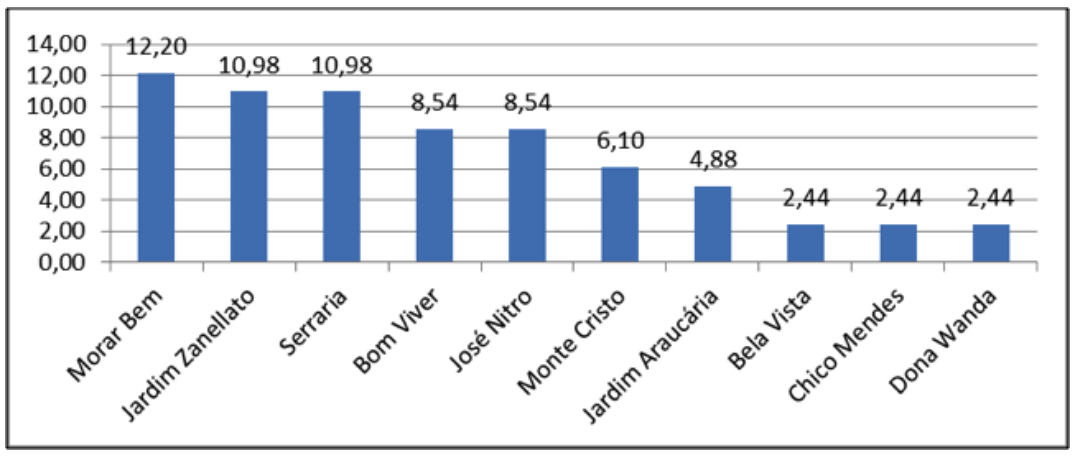

Fonte: Dados levantados pelos autores (In: CANELLA, 2015)

Os bairros Morar Bem, Jardim Zanellato, Serraria, José Nitro, Jardim Araucária, Bela Vista e Dona Wanda localizam-se em São José, ao passo que os bairros Monte Cristo e Chico Mendes em Florianópolis, e Bom Viver em Biguaçu.

Os veículos de comunicação, enquanto representantes ideológicos da fração imobiliária do capital, geralmente afirmam que os moradores das ocupações urbanas seriam, principalmente, imigrantes de outros estados, especialmente nordestinos - pessoas que não têm suas origens no modo catarinense de adequar-se ao trabalho e optam, portanto, à "invadir terras alheias". Buscando, com isto, reforçar estereótipos perigosos, ademais de criminosos e falsos, publicam essa mentira sistematicamente e acabam, por fim, convencendo a opinião pública. Os questionários aplicados na Ocupação Contestado revelaram que os responsáveis pelos domicílios possuem outra origem: em grande maioria, são catarinenses, produto das desigualdades e contradições catarinenses, não constituindo-se, com isto, em elementos estranhos à realidade estadual. São despossuídos da terra e filhos de despossuídos da terra. Alguns são pequenos produtores que perderam suas terras devido à concentração fundiária e ao empobrecimento dela decorrente. Outros, ex-trabalhadores rurais desempregados da produção do campo. Também há filhos destes, já nascidos no meio urbano, explorados no trabalho em construções, comércio e setor de serviços. 
Gráfico 6 - Estado de origem dos chefes de domicílio da Ocupação Contestado

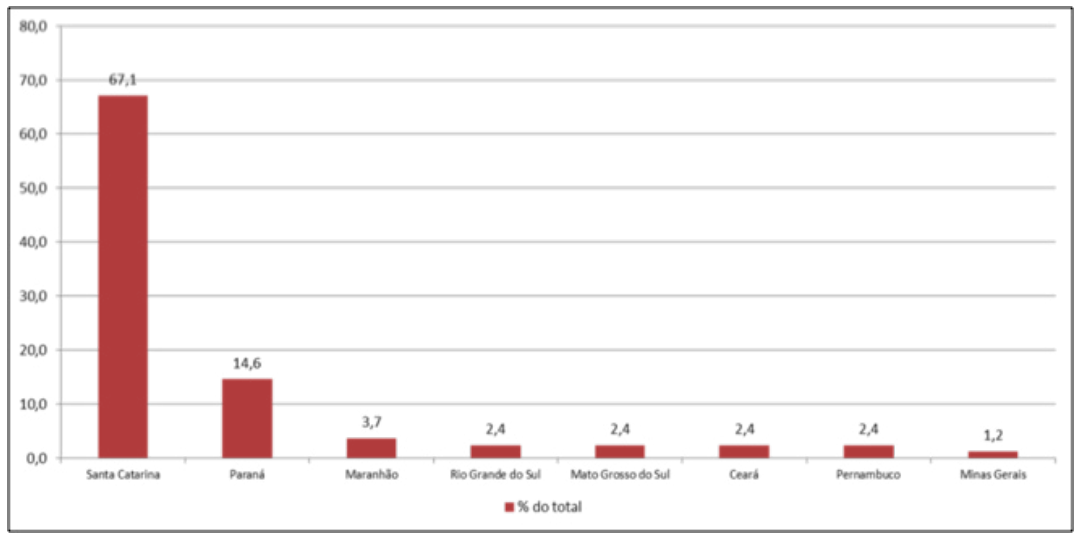

Fonte: Dados levantados pelos autores (In: CANELLA, 2015)

A religião é também um aspecto central na organização das famílias da Ocupação Contestado. Ela explica muitos elementos da dinâmica política da Ocupação. Da escolha dos nomes dos núcleos (Vida Nova e Guerreiros de Fé, por exemplo) até o poder de decisão que moradores identificados religiosamente têm quando atuam ou mesmo votam sob uma mesma direção. $\mathrm{O}$ gráfico 7 apresenta dados sobre a condição de batismo do primeiro responsável. Neste gráfico, percebe-se a predominância do batizado católico $(58,54 \%$ do total) sobre as outras formas de batizado, como o batismo evangélico (34,15\%). Um percentual de $4,88 \%$ dos primeiros responsáveis não foi batizado, e 2,44\% deles não sabe se foi batizado, nem em qual religião.

Gráfico 7. Religião de batismo do primeiro responsável do domicílio na Ocupação Contestado

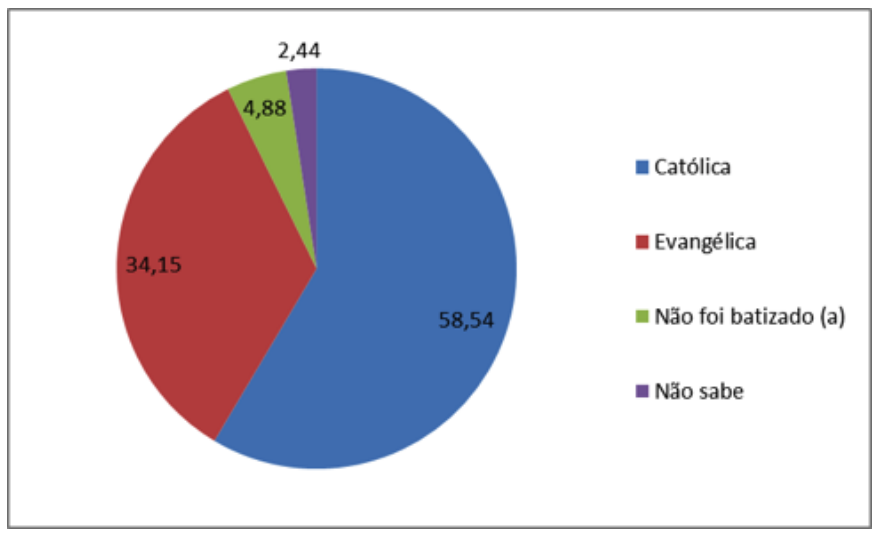

Fonte: Dados levantados pelos autores (In: CANELLA, 2015) 
Estes percentuais, no entanto, se alteram radicalmente quando perguntamos qual é a sua religião atualmente. As respostas a esta pergunta indicaram haver um amplo processo de conversão evangélica daqueles que foram batizados como católicos. Atualmente, a maior parte destes responsáveis é composta de evangélicos, como se vê no Gráfico 8.

A religião católica, que representou $58,54 \%$ dos batismos, passa a representar 30\% da religião atual. Por outro lado, as religiões neopentecostais, agrupadas como "evangélicas", que representavam $34,15 \%$ do total dos batismos, passam a representar $62,86 \%$ da religião atual.

Gráfico 8. Religião atual dos primeiros responsáveis por domicílio na Ocupação Contestado

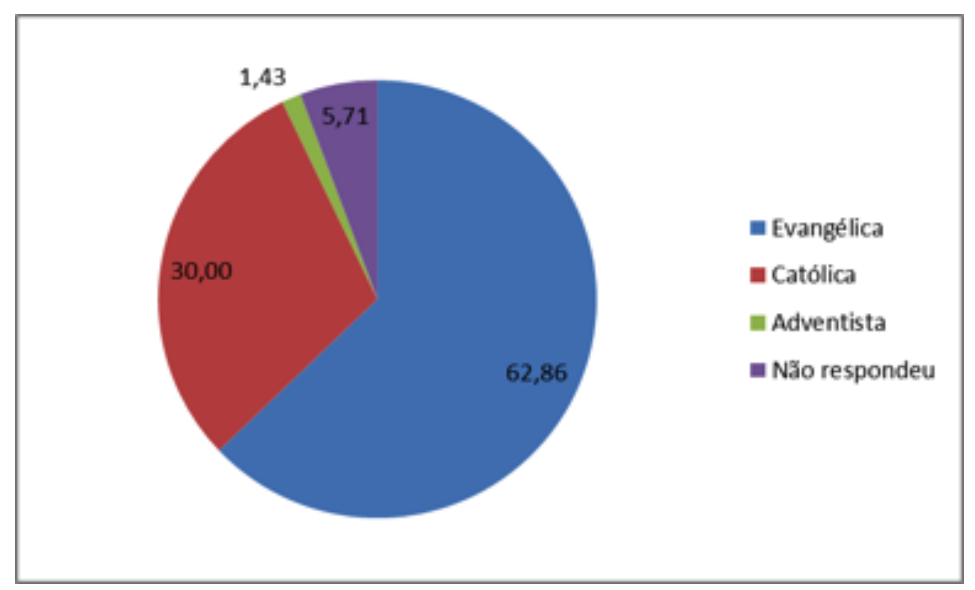

Fonte: Dados levantados pelos autores (In: CANELLA, 2015)

A escolaridade destes responsáveis por domicílio é, como indica o Gráfico 9, consideravelmente baixa, predominando os níveis de escolaridade "ensino fundamental incompleto" (35,4\% do total) e "ensino fundamental completo" (34\% do total). Nada desprezível é o percentual de $6,1 \%$ de responsáveis que nunca estudaram e de apenas $4,9 \%$ de responsáveis com ensino médio completo.

No que se refere ao trabalho, $54,88 \%$ dos responsáveis por domicílio declararam trabalhar. Destes, quase a metade $(48,89 \%)$ está empregado com carteira assinada, enquanto $8,89 \%$ está empregado sem carteira assinada. O rendimento destes trabalhadores, no entanto, não é capaz de dar garantias dignas de reprodução de sua força de trabalho. 
Gráfico 9. Escolaridade dos primeiros responsáveis pelo domicílio na Ocupação Contestado

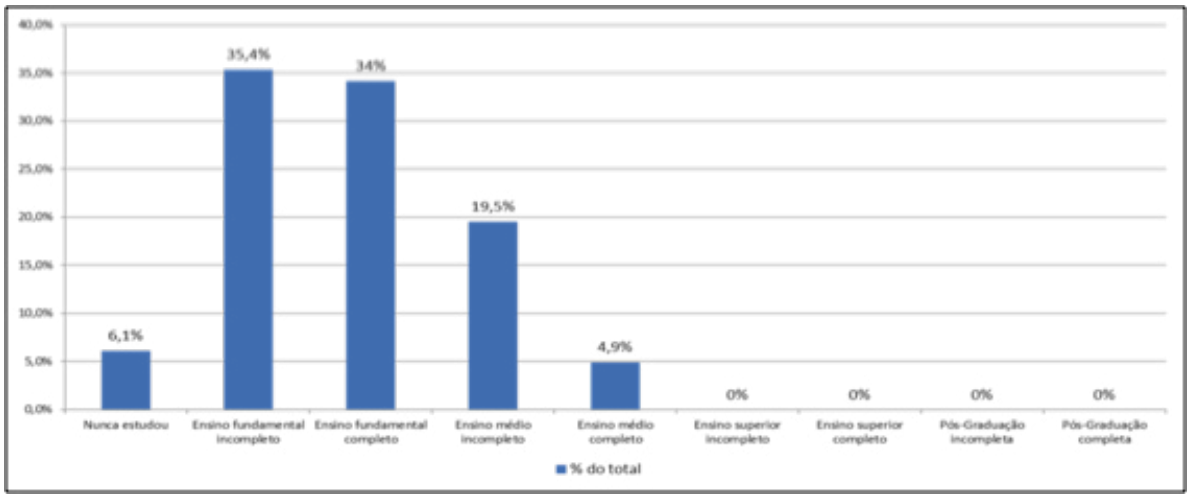

Fonte: Dados levantados pelos autores (In: CANELLA, 2015)

Calculamos a renda das famílias considerando a renda obtida por meio de trabalho, as transferências governamentais e as ajudas financeiras de parentes que não residem no domicílio; dividimos, por fim, pelo número de moradores do domicílios, de modo a obtermos a renda média mensal per capita. O resultado, conforme visto no gráfico 10, indica que a maior parte das famílias sobrevive com renda entre $\mathrm{R} \$ 200,00$ e $\mathrm{R} \$ 300,00$ por morador do domicílio, uma quantia insuficiente para a satisfação das necessidades básicas do trabalhador e de suas famílias. E poderia ser ainda pior na vigência do pagamento do aluguel mensal a que estavam submetidos antes de integrarem a Ocupação.

Gráfico 10 - Rendimento médio mensal per capita das famílias da Ocupação Contestado

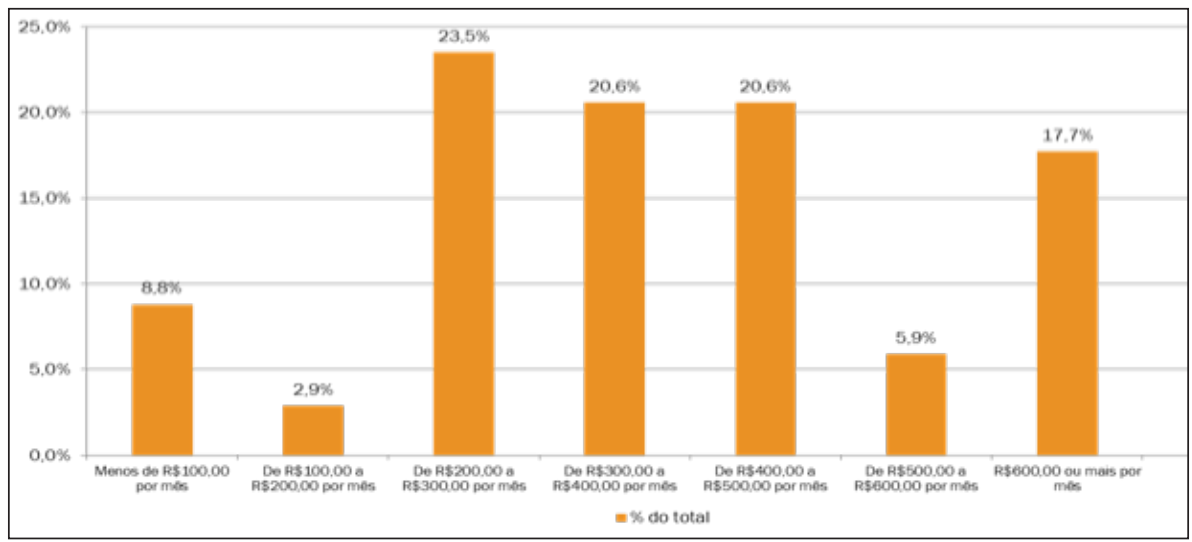

Fonte: Dados levantados pelos autores (In: CANELLA, 2015) 
Estes trabalhadores, assim como a média agregada que vimos na primeira seção deste artigo, são também objeto de superexploração da força de trabalho no tempo em que se deslocam para o trabalho e pelo qual não são pagos. Quase um terço $(31,11 \%)$ leva entre 30 minutos e uma hora apenas no trajeto de ida, o que significa que levam no mínimo uma hora por dia em tempo de deslocamento em função do trabalho que não é pago.

Gráfico 11 - Tempo de deslocamento da casa ao trabalho dos responsáveis por domicílio na Ocupação Contestado

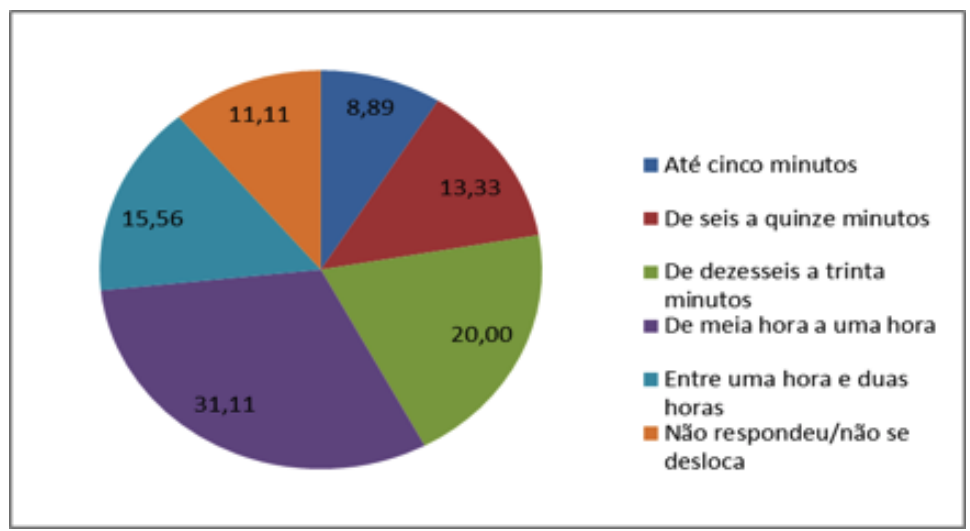

Fonte: Dados levantados pelos autores (In: CANELLA, 2015)

Exatamente a metade dos domicílios da Ocupação possui pelo menos um morador com algum problema de saúde frequente. Perguntados sobre quais seriam estes problemas de saúde, indicaram a seguinte distribuição das enfermidades:

Gráfico 12 - Principais problemas de saúde dos moradores da Ocupação Contestado

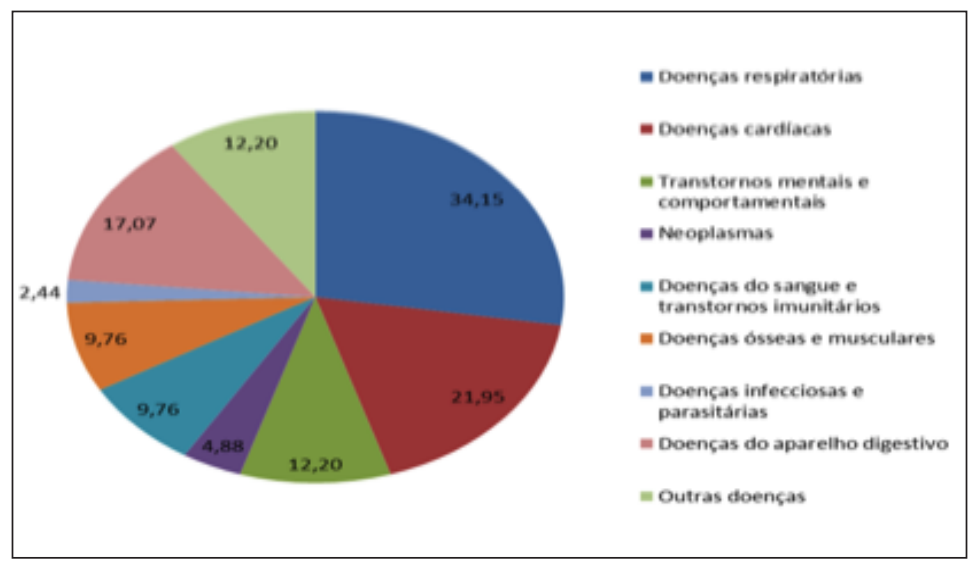

Fonte: Dados levantados pelos autores (In: CANELLA, 2015) 
A maior parte das enfermidades são relacionadas ao aparelho respiratório $(34,15 \%)$ e ao sistema cardíaco $(21,95 \%)$. Casos de dependência química e alcóolica foram catalogados como "transtornos mentais e comportamentais", a terceira forma mais comum de enfermidade na Ocupação $(12,20 \%$ do total dos casos). Chama a atenção a pequena participação das enfermidades "infecciosas e parasitárias" em relação ao total $(2,44 \%)$. Entende-se que ocorre, em realidade, uma naturalização destas enfermidades, dado que muitas crianças estão persistentemente com infecções derivadas das condições sanitárias. Ocorrendo esta naturalização, enfermidades como diarreias e vermes, de tão comuns, deixam de ser interpretadas como doenças e não são, por isto, declaradas.

Um último aspecto importante para o entendimento da realidade da Ocupação e de sua relação com as transformações demográficas, econômicas e sociais no estado é a análise das trajetórias migratórias dos moradores da Ocupação Contestado. Como vimos, a maior parte dos responsáveis pelos domicílios é nascida em Santa Catarina, especialmente na Mesorregião Oeste Catarinense $(34,62 \%$ do total), na própria Grande Florianópolis $(25,64 \%)$ e na Região Serrana (10,26\%). O maior contingente de nascidos em outros estados são paranaenses $(12,82 \%)$, e gaúchos e maranhenses (ambos com $3,85 \%)$.

Gráfico 13 - Mesorregião catarinense e Estado de origem dos responsáveis por domicílio na Ocupação Contestado

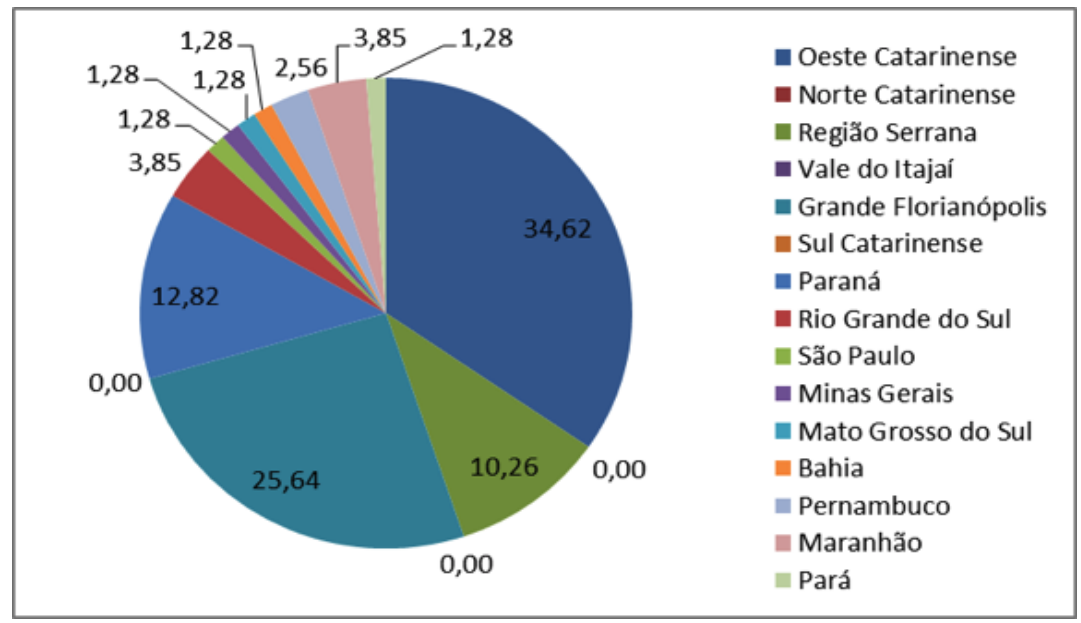

Fonte: Dados levantados pelos autores (In: CANELLA, 2015) 
Todavia, as trajetórias migratórias são tão intensas que mesmo aqueles responsáveis de domicílio nascidos em outra capital passaram por cidades do interior catarinense antes de residirem na Grande Florianópolis: 89,02\% não saíram desta outra capital diretamente para a região em que se localiza a Ocupação. A vinda diretamente para a Grande Florianópolis é mais comum entre aqueles nascidos em cidades do interior de qualquer estado, mas, ainda assim, não são a maioria: 43,9\% veio diretamente, e 50\% teve trajetórias migratórias entre a origem e o destino; 6,1\% não responderam. São, pelo exposto, migrantes internos. O gráfico 14 apresenta dados sobre o momento da chegada à Grande Florianópolis dos responsáveis por domicílio da Ocupação Contestado.

Gráfico 14 - Momento da chegada à Grande Florianópolis dos responsáveis por domicílio não naturais da Grande Florianópolis

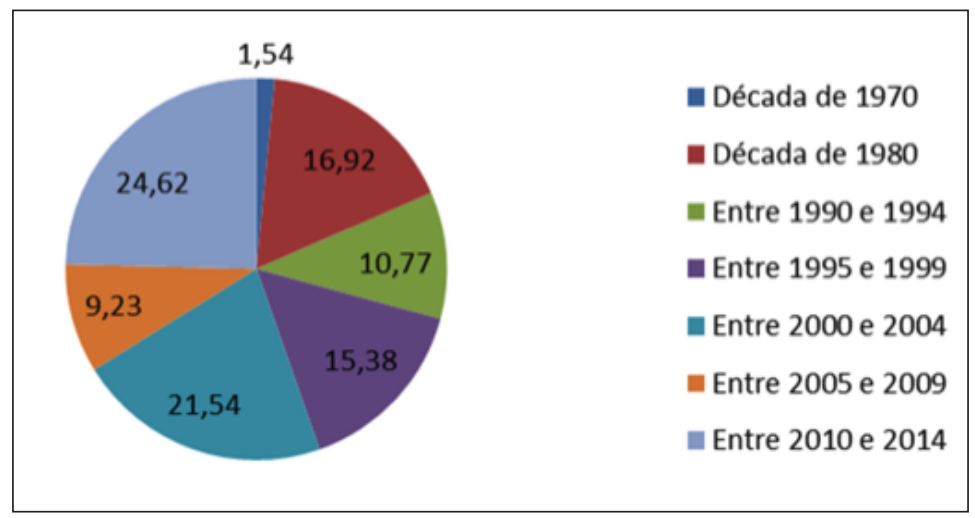

Fonte: Dados levantados pelos autores (In: CANELLA, 2015)

O Gráfico 14 indica que 24,62\% dos responsáveis por domicílio chegaram muito recentemente à Grande Florianópolis, entre 2010 e 2014. Outro percentual representativo (21,54\%) chegou entre 2000 e 2004. Mais da metade $(55,39 \%)$ passou a residir na Grande Florianópolis após o ano 2000; 44,61\% possuem mais de quinze anos de residência nesta região. Desagregando os dados acima, referentes à Grande Florianópolis, é possível analisar em qual município estes responsáveis se fixaram quando migraram para a região. $\mathrm{O}$ Gráfico 15 indica algo que guarda íntima relação com a vigência do citado projeto elitista de cidade: a diminuição progressiva, desde a década de 1990 , da participação do município de Florianópolis no contexto da chegada à Grande Florianópolis. O encarecimento dos alugueis nesta cidade e a intensa segregação sócio-espacial resulta na sua substituição por outros destinos, sobretudo São José (também desde a década de 1990) e Palhoça (esta desde 2000). 
Isto indica que os responsáveis por domicílio da Ocupação Contestado, residentes na Grande Florianópolis há mais tempo, sofreram, sim, as pressões de periferização, passando a residir mais distante do centro urbano e fora do município de Florianópolis. Os que chegaram mais recentemente, no entanto, tenderam a sequer utilizar o município de Florianópolis como etapa de sua mobilidade intraurbana. As suas redes sociais já haviam entendido que a cidade de Florianópolis é para poucos.

Gráfico 15 - Município da chegada à Grande Florianópolis segundo a década da chegada

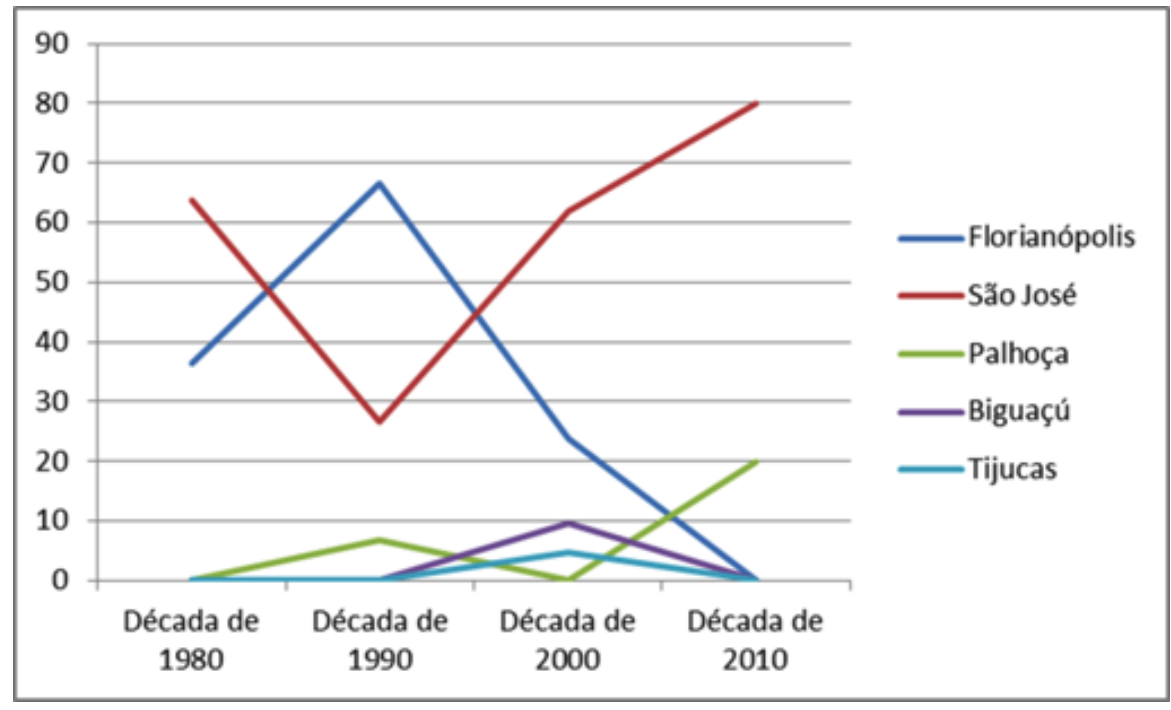

Fonte: Dados levantados pelos autores (In: CANELLA, 2015)

Entrevistamos os responsáveis por domicílio sobre os motivos das mudanças que os levaram para a Grande Florianópolis. A resposta deu-se de forma livre, sendo classificada, depois, segundo os fatores visíveis no gráfico 16. Percebe-se uma predominância daqueles motivos relacionados ao acompanhamento dos pais ou o convite de parentes $(29,92 \%)$, e os motivos relacionados ao trabalho $(28,35 \%)$. Há responsáveis por domicílio que migraram por conta do preço do aluguel e da falta de moradia digna no município anterior $(11,02 \%)$; por motivos de saúde $(7,87 \%)$; em decorrência da violência (4,72\%); e por efeito de alagamentos, questões ambientais e residência anterior em situação de risco $(1,57 \%)$. 
Gráfico 16 - Motivo das mudanças dos responsáveis por domicílio da Ocupação Contestado

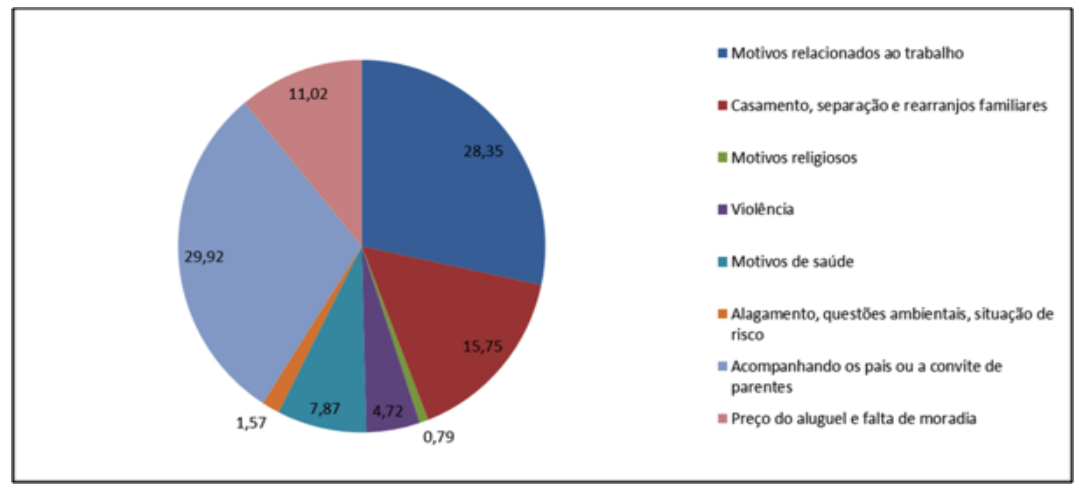

Fonte: Dados levantados pelos autores (In: CANELLA, 2015)

\section{Considerações finais}

Trabalhamos, neste artigo, com dois níveis de abstração bastante diferentes: na primeira parte, desenvolvemos uma reflexão histórica sobre as origens do processo de segregação sócio-espacial na Grande Florianópolis, definindo a construção de Florianópolis enquanto "cidade-mercadoria" como aspecto fundamental da atual conjuntura urbana. Nisto, pudemos apresentar alguns dados de modo a caracterizar mais precisamente esta situação. Na segunda parte do artigo, baixamos o grau de abstração teórica e analisamos um caso específico de resistência à esta conjuntura e suas contradições, a Ocupação Contestado, e também utilizamos alguns dados para caracterizar, social, econômica e demograficamente, os moradores da Ocupação. Com isto, tivemos a preocupação de refletir um território específico de resistência urbana à luz de uma análise mais ampla sobre as cidade e suas contradições.

Daí dizermos que a Ocupação Contestado tem suas raízes nas contradições gerais da questão urbana em um país dependente, e específicas da Grande Florianópolis. A superexploração da força de trabalho, que não permite o acesso à moradia através dos salários vigentes, é aprofundada pela elevação da renda da terra que encarece o preço dos imóveis e do aluguel numa cidade dominada pelo capital imobiliário. Esta é, portanto, a raiz de processos como o da Ocupação Contestado, que criou suas próprias referências e dirigentes políticos. Este processo, em grande medida, escapou aos limites da luta apenas institucional e apontou, aos movimentos sociais da região, a emergência do instrumento da ocupação urbana no contexto da luta 
por moradia. Avançar com este instrumento e torná-lo eficaz na obtenção da moradia digna depende, no entanto, da organização política dos trabalhadores urbanos.

Por organização política entende-se o intenso trabalho de base com as famílias. São pessoas oriundas de distintas cidades e estados, mas que identificam-se entre si por ocuparem posições subalternas nas relações econômicas e políticas da cidade. Estas relações são também relações de poder, de modo que a organização popular e o trabalho de formação das famílias têm um forte significado na disputa ideológica, e reverbera, para fora da ocupação, o exemplo de que a luta organizada realiza transformações sociais.

Desde sua criação, em novembro de 2012, a Ocupação tem sido objeto de ataques e repressões que visam, justamente, não deixar este exemplo vigorar em outros territórios da cidade que, cada vez mais, estão em disputa. Mas a luta pela transformação radical da cidade não nasceu com o Contestado, e não morrerá com a Amarildo. Ela existirá em cada pequeno agricultor que perde suas terras, em cada trabalhador rural que se vê obrigado a migrar para a cidade, em cada trabalhador urbano que percebe ser quem constrói a cidade, mas é dela alienado.

\section{Referências}

CANELLA, Francisco. O movimento sem-teto e a Ocupação Contestado: perfil social e trajetórias de vida dos moradores. Coordenador. (Projeto de Pesquisa) Florianópolis, UDESC, Fevereiro de 2015.

CMI - Centro de Mídia Independente. “A Casa que o Prefeito deu prá nós”. [Vídeo], postado por SIEMAN, Norberto, 17 nov. 2012. Disponível em: $<$ https://www.youtube.com/watch?v=4VQog9kguWM>. Acesso em: 10 jan. 2015.

DANTAS, Jéferson; VENDRAMINI, Célia Cecília. Comunidades dos morros em Florianópolis: ocupação, presença estatal e a constituição do Fórum do Morro da Cruz. In:

DIAS, Vera Lucia Nehls, PET GEOGRAFIA(Orgs.). Cadernos do Observatório Geográfico da Grande Florianóplis do PET Geografia UDESC. V. 1, p. 151-185, 2011.

DJSC - Diário de Justiça do Estado de Santa Catarina. Agravo de instrumento no 2012.087408 6. São José: 06 de dezembro de 2012. Disponível em: <http://www.jusbrasil.com.br/diarios/43995140/djsc-06-12-2012-pg-144:. Acesso em: 10 jan. 2015.

IBGE - Instituto Brasileiro de Geografia e Estatística. Censo Demográfico de 2010. Banco de Dados Agregados e Contagem da População. Disponível em: < $\underline{\text { http://www.sidra.ibge.gov.br/ }}$ cd/cd2010RgaAdAgsn.asp $>$. Acesso em: 15 jan. 2015.

KOVARICK, Lúcio. Capitalismo e marginalidade na América Latina. Rio de Janeiro: Paz e Terra, 1980. 
MARINI, Ruy Mauro; TRASPADINI, Roberta; STEDILE, João Pedro. (Orgs.). Ruy Mauro Marini. Vida e obra (Textos Selecionados). São Paulo: Expressão Popular, 2005. 296 p.

MARTINELLO, André Souza; LENZI, Maria Helena. Florianópolis e as excepcionalidades do não planejar: imagens e política da "capital dos catarinenses". In: DIAS, Vera Lucia Nehls, PET GEOGRAFIA (Orgs.). Cadernos do Observatório Geográfico da Grande Florianóplis do PET Geografia UDESC. v. 1, p. 186-206, 2011.

MIOTO, Beatriz Tamaso. Movimentos migratórios em Santa Catarina no limiar do século XXI. 2008. 85 f. Trabalho de Conclusão de Curso (Graduação - Ciências Econômicas, Ciências Econômicas), Universidade Federal de Santa Catarina, Florianópolis, 2008. Disponível em: $<$ http://tcc.bu.ufsc.br/Economia293384.pdf>. Acesso em: 01 mar. 2015.

REIS, Almir Francisco. Ilha de Santa Catarina. Permanências e transformações. Florianópolis: Ed. Da UFSC, 2012. 284 p.

REVISTA VISÃO. Florianópolis. Lugar seguro: apenas um assalto em 1980. Lages - SC, 23 de Fevereiro de 1981.

SHERWOOD, Seth. The Place to be: Florianópolis, Brazil. The New Yor Times. Florianópolis Travel Coverage. Jan, 08, 2009. Disponível em: <http://www.nytimes.com/travel/guides/central-and-south-america/brazil/florianopolis/overview.html $>$. Acesso em: 17 jan. 2015.

SPU - Superintendência do Patrimônio da União. Oficio $N^{o}$ 1911/2012 - GAB/SPU/SC, Florianópolis, 06 dez. 2012.

VILLAÇA, Flávio. Uso do solo urbano. 1 a ed. São Paulo: Centro de Estudos e Pesquisas de Administração Municipal, 1978. 71 p.

Espaço Intra-urbano no Brasil. São Paulo: Studio Nobel, FAPESP, 2001. 373p.

TORTATO, Mari. PF conclui inquérito da Operação Moeda Verde e aumenta lista de indiciados. Folha de São Paulo. São Paulo, 15 out. 2007. Poder, p. 1-1. Disponível em: <http:// www1.folha.uol.com.br/poder/2007/10/336961-pf-conclui-inquerito-da-operacao-moeda-verde-e-aumenta-lista-de-indiciados.shtml>. Acesso em: 15 out. 2007.

Submissão em: 10/02/2015

Aceite em: 03/09/2015

Luís Felipe Aires Magalhães é doutorando no Programa de Pós-Graduação em Demografia da Universidade Estadual de Campinas - UNICAMP. Militante das Brigadas Populares. Endereço para correspondência: Rua João Pio Duarte Silva, 264, bloco C, apto 202 - Bairro Córrego Grande, Florianópolis. CEP: 88037 - 000. E-mail: lufeaires@gmail.com

Vitor Hugo Tonin é doutorando no Programa de Pós-Graduação em Desenvolvimento Econômico da Universidade Estadual de Campinas UNICAMP. Militante das Brigadas Populares. E-mail:vitorht@gmail.com 